\title{
Study of the stability of the 5-aminolevulinic acid tyrosine ester in aqueous solution
}

\author{
Sandrine Gay, ${ }^{\mathrm{a}}$ Carla Martoccia, ${ }^{\mathrm{a}}$ Matthieu Zellweger, ${ }^{\mathrm{a}}$ Qian Wang, and Georges \\ Wagnières $^{\mathrm{a} *}$ \\ ${ }^{a}$ LCOM (Medical Photonics Group), Swiss Federal Institute of Technology (EPFL), SB-ISIC, \\ Station 6, CH-H5, 1015 Lausanne, Switzerland \\ ${ }^{b}$ LSPN, Swiss Federal Institute of Technology (EPFL), SB-ISIC, Avenue Forel 2, 1015 Lausanne, \\ Switzerland \\ E-mail: georges.wagnieres@epfl.ch
}

DOI:http://dx.doi.org/10.3998/ark.5550190.p008.469

\begin{abstract}
Photodynamic therapy based on photoactivable porphyrins (PAPs) can treat various dermatological conditions. The side-effects as well as the non-selective or insufficient accumulation of PAPs in the targeted tissues limit performances. We studied the stability in solution at different temperatures $\left(21^{\circ} \mathrm{C} ; 4^{\circ} \mathrm{C}\right)$, different $\mathrm{pH}$ values $(7.5 ; 2.0)$, and as a function of time of 5-aminolevulinic acid's Tyrosine-ester, a molecule presenting interesting properties to selectively produce PAPs in blood vessels after topical application. Solutions of this precursor can be kept up to $24 \mathrm{~h}$ at refrigerated temperatures and under acidic $\mathrm{pH}$. At room temperature or physiological $\mathrm{pH}$, they must be prepared minutes before their use.
\end{abstract}

Keywords: 5-Aminolevulinic acid, stability, 5-aminolevulinic acid derivatives, photodynamic therapy, tyrosine ester

\section{Introduction}

Photodynamic therapy (PDT) based on the topical application of 5-aminolevulinic acid (ALA) or some of its derivatives, as exogenous precursors of fluorescent and photoactivable porphyrins (PAPs), such as protoporphyrin IX (PPIX - for the sake of clarity, the abbreviation «PPIX » will be used throughout instead of « photoactivable porphyrins (PAPs), such as protoporphyrin IX»), is widely used in various fields of medicine for cancerous and non-cancerous applications. This modality of treatment (or detection) has numerous advantages, such as the facts that it is a local treatment, that neither the precursors nor the PPIX are toxic in the absence of light, and that the accumulation of PPIX is somewhat selective for certain hyperplastic, or hyper-metabolic tissues. 
Due to these properties, PPIX-based PDT is a treatment of choice for various dermatological conditions, such as Actinic Keratosis (AK), basal cell carcinoma (BCC), as well as other skin pathologies ${ }^{1}$.

Despite these clear advantages, the limited specific production of PPIX within the tissues to be destroyed, in particular in blood vessels when treating conditions such as telangiectasia, portwine stain, or rosacea, limits the performance of PDT treatment. To overcome this problem, one strategy is to target cells present in the wall of skin blood vessels. The concept is that if a given precursor demonstrates selectivity for these cells, they will biosynthesize PPIX preferentially compared to other cells in the vicinity ${ }^{2}$. This approach is interesting not only for oncologic applications $^{3}$ but also for treatment of any condition of vascular origin, as is the case for the conditions mentioned above.

We synthesized one new ALA derivative, ALA-tyrosine-ester (ALA-Tyr). Based on preliminary results obtained in a separate in vivo study, this molecule presents an improved vascular selectivity compared to ALA. Since it is likely that only free ALA participates in the biosynthesis of PPIX ${ }^{4}$, the stability of the ester bond has an impact on the bioavailability of ALA in the targeted cell after the precursor has been internalized. Thus, we study ALA-Tyr's stability properties. We also present results obtained in similar solutions with free ALA. We investigate the stability of ALA-Tyr in solution at two different temperatures $\left(21^{\circ} \mathrm{C}\right.$ and $\left.4{ }^{\circ} \mathrm{C}\right)$, and at two different $\mathrm{pH}$ values (2.0 and 7.5), and at various time points between $1 \mathrm{~h}$ and $24 \mathrm{~h}$. It is noteworthy that under these conditions, free $\mathrm{ALA}^{5,6}$ and ALA-Tyr are both unstable ${ }^{7}$, but degrade via different pathways: ALA-Tyr degrades through the hydrolysis of the ester bond, whilst free ALA dimerizes, forming 2,5-dicarboxyethyl-3,6-dihydropyrazine (DHPY), and 2,5dicarboxyethylpyrazine (PY) after oxidation in the presence of molecular oxygen ${ }^{8}$.

\section{Results and Discussion}

The structure of the 5-aminolevulinic acid derivative 5-ALA-Tyr ester (1) is shown in Figure 1.

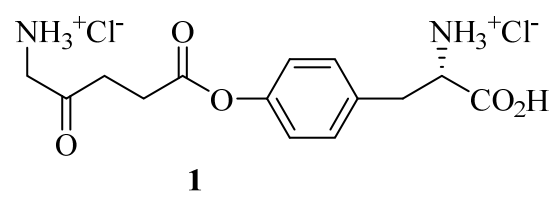

Figure 1. Structure of 5-ALA-Tyr ester (1).

$N$-BocALA (3) was synthesized according to published methods, starting from commercially available 5-aminolevulinic acid hydrochloride (2) ${ }^{9}$ (see Figure 2). 


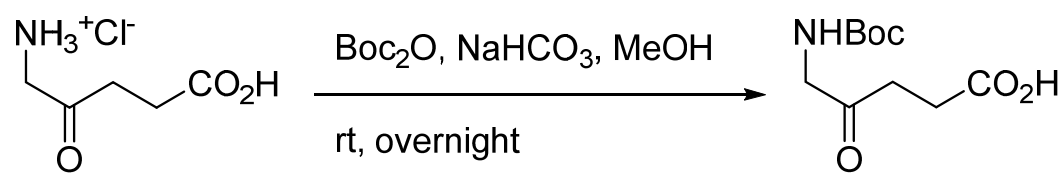

Figure 2. Synthesis of N-BocALA (3).

5-ALA-Tyr ester (1) was synthesized starting from $N$-BocALA (3) and commercially available Tyr-OBu ${ }^{t}(\mathbf{4})$ according to published method (see Figure 3 ). ${ }^{10}$
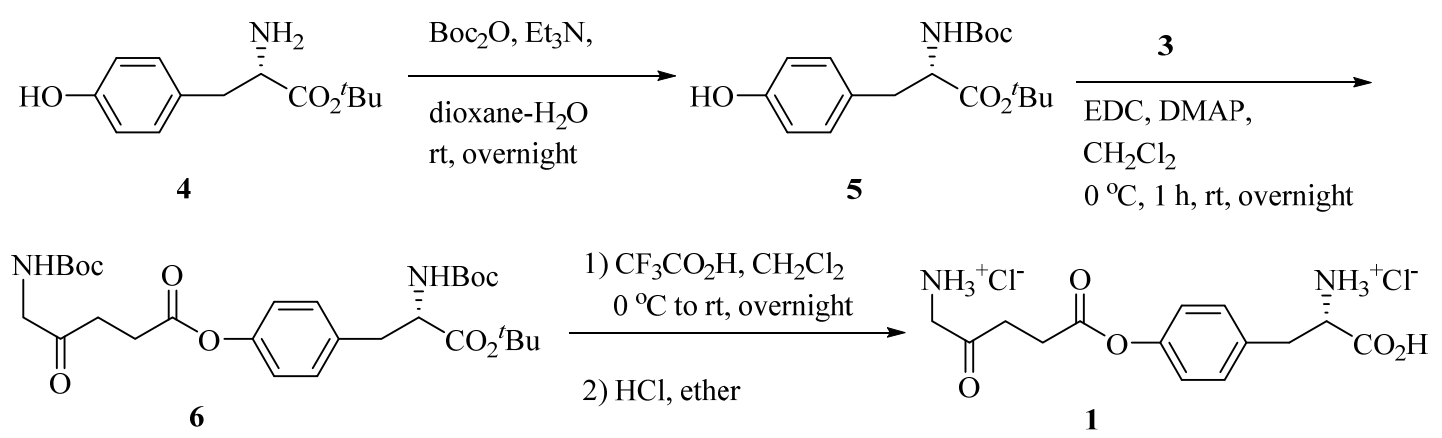

Figure 3. Synthesis of 5-ALA-Tyr ester (1).

Figure 4 shows the chromatogram of the ALA-Tyr ester in solution $(10 \mathrm{mg} / \mathrm{ml}$ in PBS, further diluted for the measurement to $1 \mathrm{mg} / \mathrm{ml}$, see Experimental Section) at two different time points $(\mathrm{t}=0$ and $\mathrm{t}=24 \mathrm{~h})$ and under various storage conditions. For the sake of readability, a diagonal offset was applied to the $\mathrm{t}=24 \mathrm{~h}$ chromatogram both horizontally and vertically. Individual peaks are identified with markers.

Figure 4a shows the chromatograms of the ALA-Tyr solution stored at temperature $\mathrm{T}=21^{\circ} \mathrm{C}$ and at $\mathrm{pH}=7.5$. Figure $4 \mathrm{~b}$ shows the chromatograms of the solution stored at $4^{\circ} \mathrm{C}$ and at $\mathrm{pH}=2$. We chose these two sets of conditions because they represent the two extremes in terms of stability of the ALA-Tyr solution. Please note that a scaling factor was applied to Fig. $4 \mathrm{~b}$ to compensate for different daily calibration parameters.

On Figure 4a, it can be noted that the intensity of the peak corresponding to ALA-Tyr ester decreases after $24 \mathrm{~h}$ (upper chromatogram). A concomitant increase in the intensity of the peak corresponding to ALA can be observed. A similar increase in intensity can be observed for the peak corresponding to free Tyrosine. These observations confirm our hypothesis that the ALATyr ester is hydrolyzed into ALA and free Tyrosine over $24 \mathrm{~h}$ at temperature $\mathrm{T}=21^{\circ} \mathrm{C}$ at $\mathrm{pH}=$ 7.5. Some additional peaks are residues from the synthetic process. They are not detected with other analytical methods, and only appear in the chromatogram due to their good ionization properties. It is however noteworthy that the peak corresponding to BOC-protected ALA-Tyr ester (third peak from left) follows the same evolution and decreases, whilst the peak 
corresponding to BOC-protected free Tyrosine (second peak from left) increases, showing that the ester-bond of the BOC-protected moieties are also hydrolyzed over time.
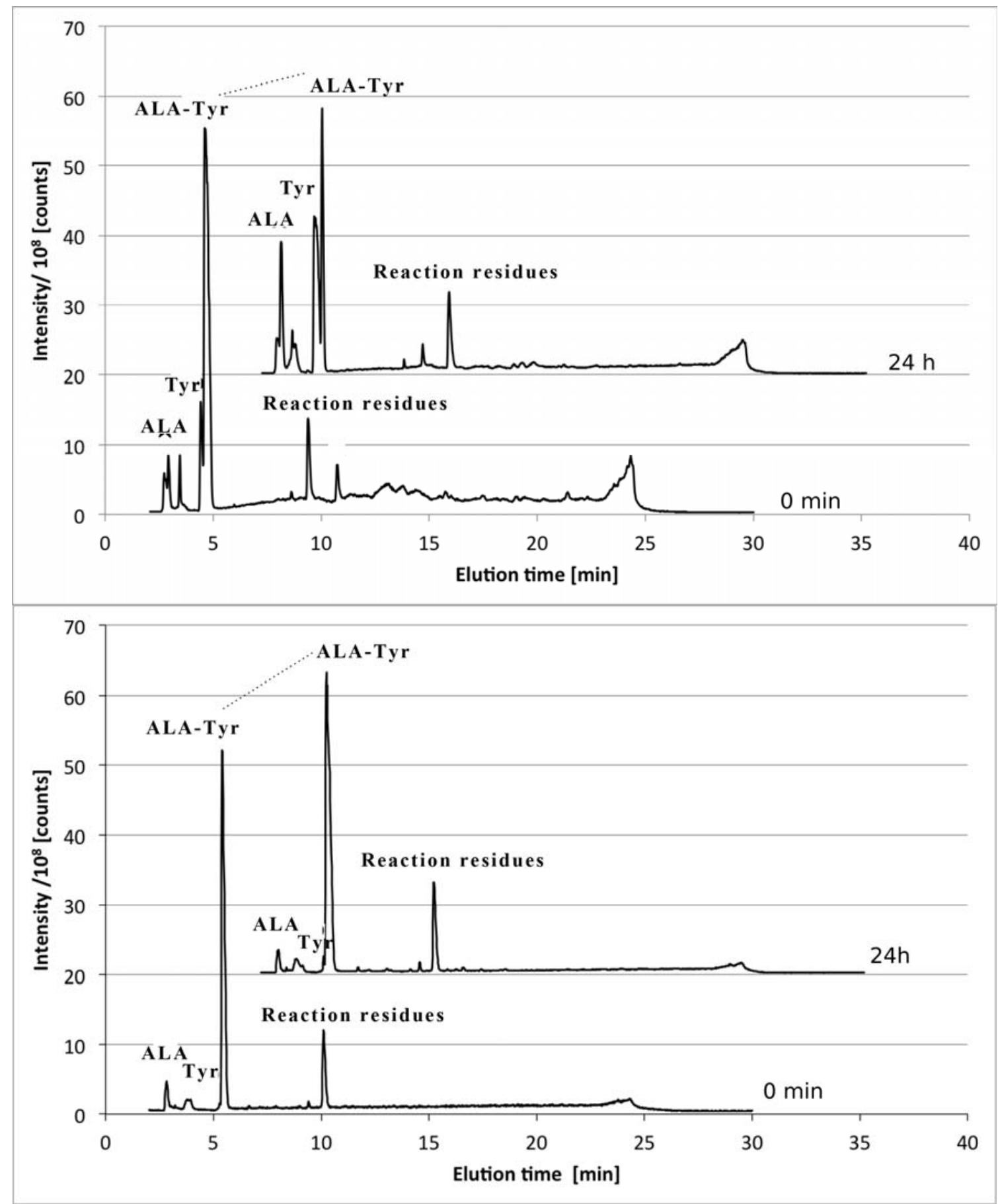

Figure 4. Chromatograms of $1 \mathrm{mg} / \mathrm{mL}$ ALA-Tyr solutions at different storage conditions. A (top) : stored at $\mathrm{pH} 7.5$ and room temperature during $24 \mathrm{~h} ; \mathrm{B}$ (bottom) : stored at $\mathrm{pH} 2$ at $4{ }^{\circ} \mathrm{C}$ during $24 \mathrm{~h}$. 
On Figure 4b, we observe a very different situation. Some free Tyrosine can be detected after $24 \mathrm{~h}$, but in minute amounts only (approximately 5\%). Generally speaking, the chromatogram at $24 \mathrm{~h}$ shows that these storage conditions keep the precursor solution in a much more stable state.

Figure 5 shows a more general view of the kinetics of the hydrolysis of the ester bond of ALA-Tyr ester under four $\mathrm{pH}$ and temperature storage conditions, namely $\mathrm{pH}=7.5 \&$ temperature $\mathrm{T}=21^{\circ} \mathrm{C}$ (see also Fig. 4a); $\mathrm{pH}=7.5 \&$ temperature $\mathrm{T}=4^{\circ} \mathrm{C} ; \mathrm{pH}=2.0 \&$ temperature $\mathrm{T}=21^{\circ} \mathrm{C} ; \mathrm{pH}=2.0 \&$ temperature $\mathrm{T}=4^{\circ} \mathrm{C}$ (see also Fig. $4 \mathrm{~b}$ ).

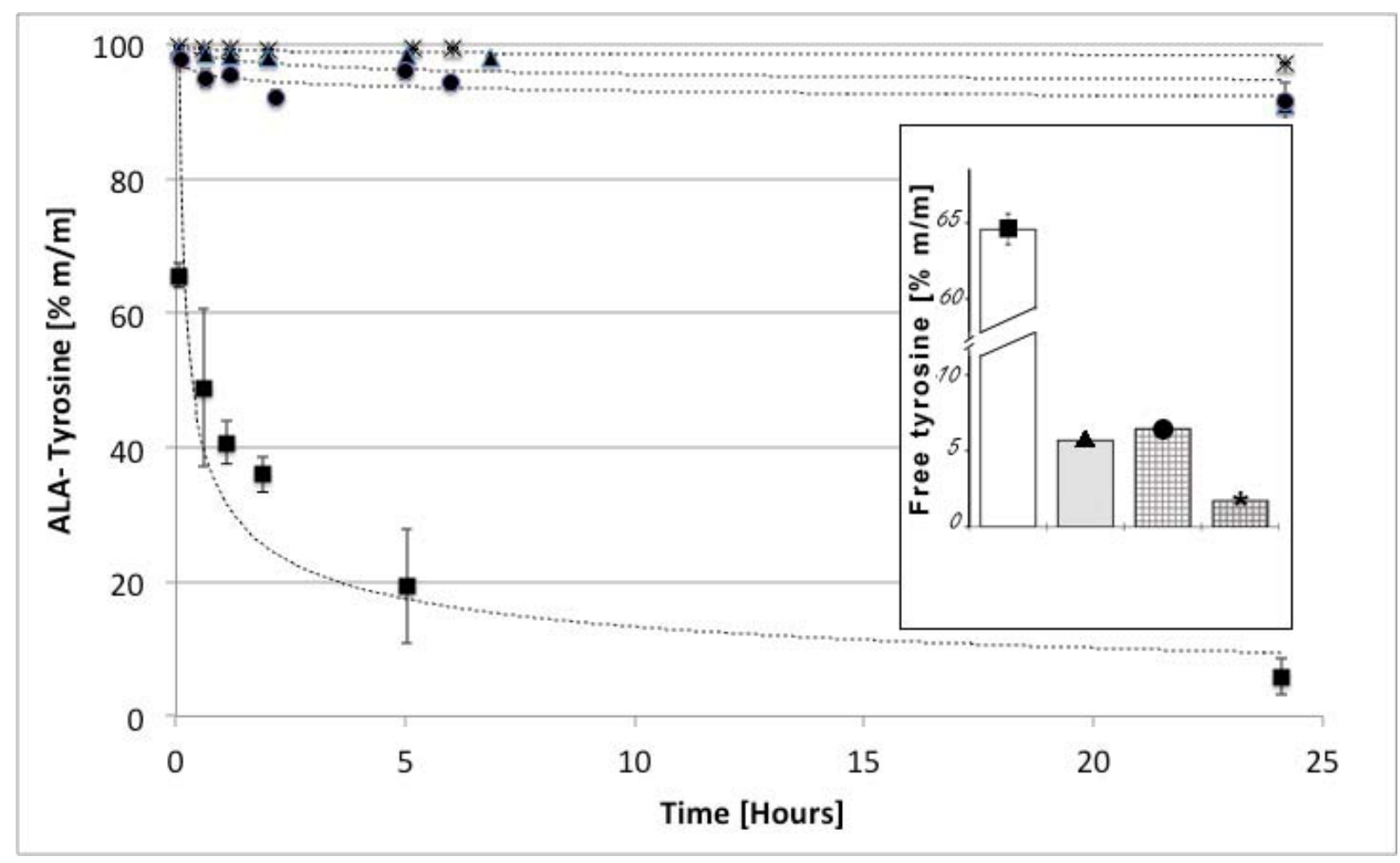

Figure 5. Kinetic profiles of ALA-tyr hydrolyse in different conditions of storage. $\mathbf{p H} 7.5$ at room temperature; $\mathrm{pH} 7.5$ at $4{ }^{\circ} \mathrm{C} ; \boldsymbol{\Delta} \mathrm{pH} 2$ at room temperature; $* \mathrm{pH} 2$ at $4{ }^{\circ} \mathrm{C}$.

Inset: percentage of free tyrosine at $24 \mathrm{~h}$ (vertical scale varies in the inset). Results are significant to $\mathrm{p} \leq 0.05$.

The measurement reported on Fig. 5 is the percentage of ALA-Tyr in solution relative to its initial concentration. More than $90 \%$ of the original quantity of ALA-Tyr remains after $24 \mathrm{~h}$ in the stable solutions (those labeled $*$ and $\mathbf{\Delta}$ ), whereas a smaller percentage of ALA-Tyr ester (approximately $90 \%$ and $<10 \%$ of the original quantity, respectively) remains in the other two solutions (those labeled $\boldsymbol{O}$ and $\boldsymbol{\square}$ ). It can be seen from Figure 5 that both temperature and $\mathrm{pH}$ have a large impact on the stability of ALA-Tyr in solution. The storage conditions $\mathrm{pH}=7.5 \&$ temperature $\mathrm{T}=21{ }^{\circ} \mathrm{C}$ (curve labeled $\boldsymbol{\square}$, see also Fig. 4a) are the least favorable for ALA-Tyr ester's stability, whilst $\mathrm{pH}=2.0 \& 4^{\circ} \mathrm{C}$ (curve labeled $*$, see also Fig. $4 \mathrm{~b}$ ) are the most 
favorable. The inset gives a magnified view of the measurement at $24 \mathrm{~h}$, and shows the percentage of free Tyrosine under the same conditions. Both $\mathrm{pH}$ and temperature have an impact on the stability of ALA-Tyr ester in solution. The two parameters are not completely independent. The inset shows that at temperature $\mathrm{T}=21{ }^{\circ} \mathrm{C}$, keeping the $\mathrm{pH}=2.0$ limits the percentage of free Tyrosine to approximately $5 \%$ of its original quantity after $24 \mathrm{~h}$. Lowering the temperature to $4{ }^{\circ} \mathrm{C}$ allows to bring the percentage of free Tyrosine to approximately $7 \%$ of its original quantity. The results shown in the inset are significant $(\mathrm{p}<0.05)$. Figure 5 shows that, amongst conditions chosen because they reflect frequent clinical practice (solutions prepared fresh or prepared the day before; physiological or acidic $\mathrm{pH}$; solutions stored in a fridge or at room temperature; etc), the sets of conditions showed differences of limited magnitude in several cases.

Figure 6 shows the chromatogram of an ALA solution stored at temperature $\mathrm{T}=21^{\circ} \mathrm{C}$ over time $(\mathrm{t}=0$ until $\mathrm{t}=24 \mathrm{~h})(10 \mathrm{mg} / \mathrm{ml}$ in PBS, further diluted for the measurement to $2.5 \mathrm{mg} / \mathrm{ml}$, see Experimental Section). Two peaks are noteworthy: the peak corresponding to ALA-ALA dimer PY, appears and grows over time; the peak corresponding to ALA decreases over time, albeit in a slightly less clear-cut manner.

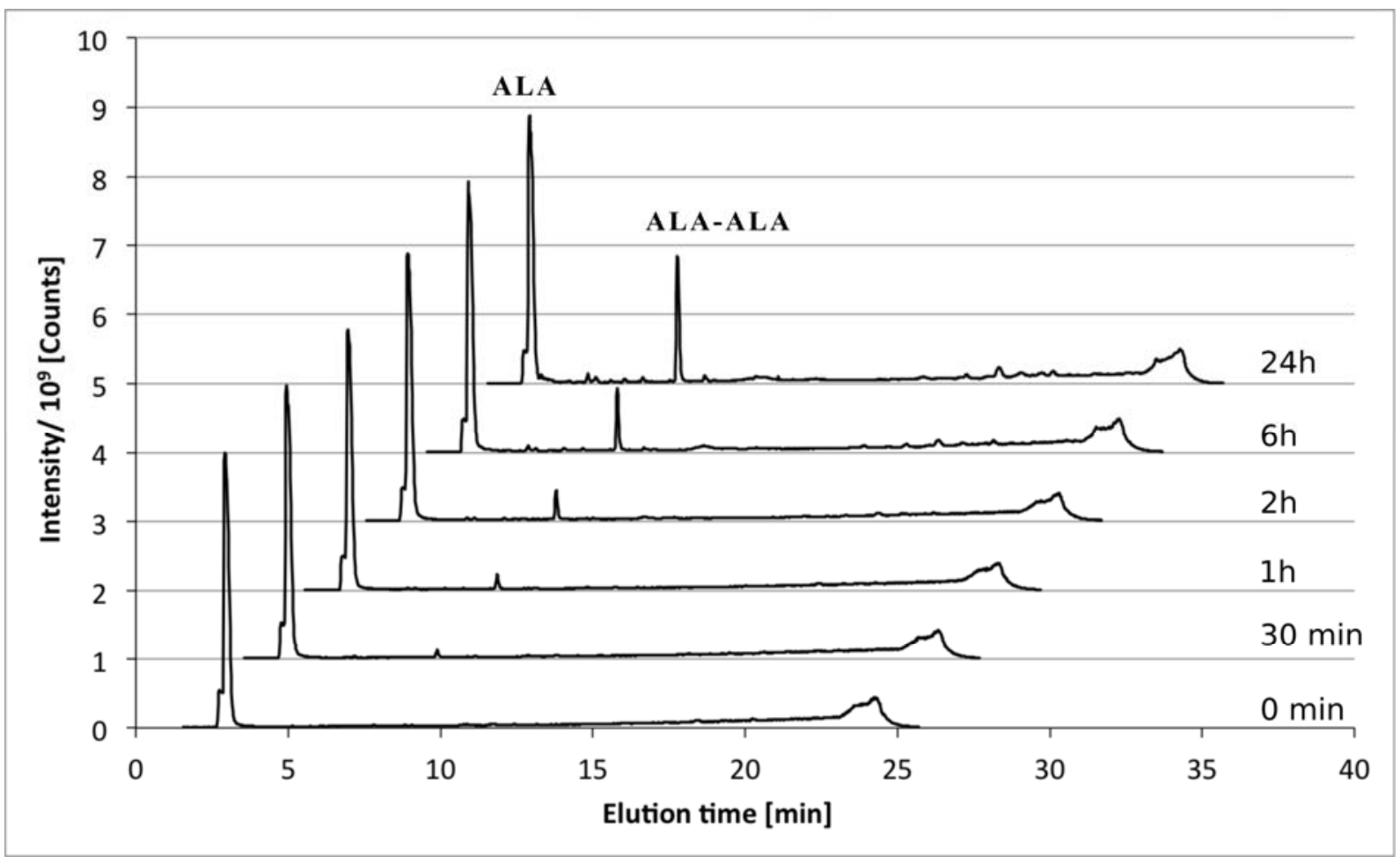

Figure 6. Chromatograms of $2.5 \mathrm{mg} / \mathrm{mL}$ ALA solution stored at $\mathrm{pH} 7.5$ and room temperature after $0 \mathrm{~min}, 30 \mathrm{~min}, 1 \mathrm{~h}, 2 \mathrm{~h}, 6 \mathrm{~h}$ and $24 \mathrm{~h}$.

Table 1 summarizes the retention times of ALA and some of its derivatives on our LC-MS 
system. The retention times give an idea of the relative hydrophobicity of the various derivatives, with longer retention times corresponding to a higher hydrophobicity.

Table 1. Retention times of various ALA derivatives of interest for PDT treatments measured with our LC-MS system

\begin{tabular}{cc}
\hline Derivative & Retention time on our system [min.] \\
\hline ALA & 2.9 \\
ALA Methyl-ester & 3.7 \\
ALA-ALA dimer (PY) & 3.8 \\
ALA Tyrosine-ester & 5.2 \\
ALA Hexyl-ester & 14.8 \\
\hline
\end{tabular}

Our results demonstrate that the parameters we studied (temperature and $\mathrm{pH}$ of the storage solution) affect the stability of ALA-Tyr in solution. This is in good agreement with previous results reported for $\mathrm{ALA}^{6,11}$ or some of its esters ${ }^{12}$, and shows that both ALA and ALA-Tyr solutions can be kept for up to 24 hours if they are refrigerated and their $\mathrm{pH}=2$, but must otherwise be prepared within minutes before their use.

\section{Conclusions}

We measured the hydrolysis of the ester bond in solutions of ALA-Tyr. The end-point for the degradation of the derivatives was the appearance of free Tyrosine, and the disappearance of ALA-Tyr ester. Both $\mathrm{pH}$ and temperature have an impact on the stability of ALA-Tyr ester in solution. At temperature $\mathrm{T}=21^{\circ} \mathrm{C}$, keeping the $\mathrm{pH}=2.0$ limits the hydrolysis of the ester bond of ALA-Tyr ester to approximately $10 \%$ after $24 \mathrm{~h}$ (see Fig. 5). Conversely, lowering the temperature to $4^{\circ} \mathrm{C}$ allows to bring the hydrolysis rate of ALA-Tyr ester at less than $10 \%$ after 6 $\mathrm{h}$ at neutral $\mathrm{pH}$ (vs. $>80 \%$ at temperature $\mathrm{T}=21^{\circ} \mathrm{C}$, see Fig. 5). Thus, the impact of keeping the $\mathrm{pH}$ at acidic value is larger than the impact of lowering the temperature.

Based on these results, we can conclude that it is necessary to keep the solutions of ALA or ALA-Tyr refrigerated, and to use them within $24 \mathrm{~h}$ of their preparation. This is particularly important for solutions at neutral (physiological) $\mathrm{pH}$.

\section{Experimental Section}

General. Reagents and solvents were purchased from commercial sources (Aldrich, Acrôs, Merck, Fluka, Fluorochem and VWR international). Reagents were used without further purification unless otherwise noted. All reactions were performed under argon (or nitrogen). When needed, glassware was dried overnight in an oven $\left(\mathrm{T}>100{ }^{\circ} \mathrm{C}\right)$ or under vacuum with a 
heat gun $\left(\mathrm{T}>200{ }^{\circ} \mathrm{C}\right)$. When solvents were indicated as dry, they were either purchased as such or distilled prior to use or dried by a passage through a column of anhydrous alumina or copper using a Puresolv MD 5 from Innovative Technology Inc., based on the Grubbs' design ${ }^{13}$. Flash column chromatography was performed using Silicycle silica gel: 230-400 mesh (40-63 $\mu \mathrm{m})$ silica. Reactions were monitored using Merck Kieselgel $60 \mathrm{~F}_{254}$ aluminium plates. TLC's were visualized by UV fluorescence $(254 \mathrm{~nm})$ then one of the following: $\mathrm{KMnO}_{4}$, phosphomolybdic acid, ninhydrin, vanillin. NMR spectra were recorded on a Brüker AvanceIII-400, Brüker Avance-400 or Brüker DPX-400 spectrometer at room temperature, ${ }^{1} \mathrm{H}$ frequency is at 400.13 $\mathrm{MHz},{ }^{13} \mathrm{C}$ frequency is at $100.62 \mathrm{MHz}$. Chemical shifts $(\delta)$ were reported in parts per million (ppm) relative to residual solvent peaks rounded to the nearest 0.01 for proton and 0.1 for carbon (ref: $\mathrm{CDCl}_{3}\left[{ }^{1} \mathrm{H}: 7.26,{ }^{13} \mathrm{C}: 77.2\right], \mathrm{CD}_{3} \mathrm{OD}\left[{ }^{1} \mathrm{H}: 3.31,{ }^{13} \mathrm{C} 49.0\right], d_{6}-\mathrm{DMSO}\left[{ }^{1} \mathrm{H}: 2.50,{ }^{13} \mathrm{C} 39.5\right]$ ). Coupling constants $(J)$ are reported in $\mathrm{Hz}$ to the nearest $0.1 \mathrm{~Hz}$. Peak multiplicity was indicated as follows s (singlet), d (doublet), t (triplet), q (quartet), $\mathrm{m}$ (multiplet) and br (broad). Attribution of peaks was done using the multiplicities and integrals of the peaks. The accurate masses were measured by the mass spectrometry service of the EPFL by ESI-TOF using a QTOF Ultima from Waters or APPI-FT-ICR using a linear ion trap Fourier transform ion cyclotron resonance mass spectrometer from Thermo Scientific.

$\mathrm{N}$-BocALA (5-((tert-butoxycarbonyl)amino)-4-oxopentanoic acid) (3). ${ }^{9}$ A suspension of 5ALA hydrochloride (2) (5.00 g, $29.8 \mathrm{mmol}), \mathrm{NaHCO}_{3}(15.04 \mathrm{~g}, 179.0 \mathrm{mmol})$, and di-tert-butyl dicarbonate $(6.51 \mathrm{~g}, 29.8 \mathrm{mmol})$ in dry $\mathrm{MeOH}$ was stirred at room temperature overnight. The solid was removed by filtration, and the solvent was evaporated. The oily residue was dissolved in water, and the aqueous solution was acidified with $10 \%$ aqueous $\mathrm{KHSO}_{4}$ to $\mathrm{pH} 2$. The mixture was extracted with EtOAc. The organic layers were washed with brine, dried over $\mathrm{Na}_{2} \mathrm{SO}_{4}$, filtered, and evaporated. The oily residue was purified by column chromatography on silica gel $\left(\mathrm{CH}_{2} \mathrm{Cl}_{2} / \mathrm{MeOH}=10 / 1\right)$ to give $N$-BocALA (3) $(6.24 \mathrm{~g}, 90 \%)$ as a white solid, mp $72-74{ }^{\circ} \mathrm{C}$ (lit. ${ }^{8}$ 74-77 $\left.{ }^{\circ} \mathrm{C}\right)$. The spectroscopic data of compound 3 were identical to those reported in the literature ${ }^{9}$.

$\mathrm{N}$-Boc-Tyr(OH)-OBu ${ }^{t}((S)$-tert-butyl 2-((tert-butoxycarbonyl)amino)-3-(4-hydroxy-phenyl)propanoate) (5). To a stirred solution of $\mathrm{Tyr}_{-} \mathrm{OBu}^{t}$ (4) $(5.0 \mathrm{~g}, 21.0 \mathrm{mmol})$ in dioxane and water $(42 \mathrm{ml}, 0.5 \mathrm{M}$, dioxane/water $=1 / 1)$ were added $\mathrm{Et}_{3} \mathrm{~N}(3.27 \mathrm{~g}, 4.5 \mathrm{~mL}, 32.3 \mathrm{mmol}, 1.54$ equiv $)$ and $(\mathrm{Boc})_{2} \mathrm{O}$ (5.56 g, $24.4 \mathrm{mmol}, 1.14$ equiv). The reaction mixture was stirred at $\mathrm{rt}$ overnight. After confirming the completion of the reaction by TLC, the reaction mixture was acidified to $\mathrm{pH} 3$ by adding $10 \%$ aqueous $\mathrm{KHSO}_{4}$, and extracted with EtOAc. The organic layers were washed with brine, dried $\left(\mathrm{Na}_{2} \mathrm{SO}_{4}\right)$ and evaporated. Column chromatography on silica gel (petroleum ether/EtOAc $=20 / 1$ then $2 / 1)$ to yield $N$-Boc-Tyr $(\mathrm{OH})-\mathrm{OBu}^{t}$ (5) $(6.82 \mathrm{~g}, 96 \%)$ as a white solid, mp 106-107 ${ }^{\circ} \mathrm{C}$ (lit. ${ }^{12} 112.8-113.0{ }^{\circ} \mathrm{C}$ (nhexane/ $\left.\mathrm{CH}_{2} \mathrm{Cl}_{2}\right)$ ). The spectroscopic data of compound 5 were identical to those reported in the literature ${ }^{14}$.

$N$-Boc-5-ALA-Tyr-OBu ${ }^{t}$ ester ((S)-4-(3-(tert-butoxy)-2-((tert-butoxycarbonyl)amino)-3oxopropyl)phenyl 5-((tert-butoxycarbonyl)amino)-4-oxopentanoate) (6). To a stirred solution 
of $N$-Boc-Tyr(OH)-OBu ${ }^{t}$ (5) (2.26 g, $\left.6.70 \mathrm{mmol}\right), N$-BocALA (3) (1.55 g, $6.70 \mathrm{mmol}, 1.0$ equiv) and DMAP (8.1 mg, $0.067 \mathrm{mmol}, 0.01$ equiv) in dry $\mathrm{CH}_{2} \mathrm{Cl}_{2}(135 \mathrm{~mL}, 0.05 \mathrm{M})$ at $0{ }^{\circ} \mathrm{C}$ was added EDC (1.54 g, 8.04 mmol, 1.2 equiv). The reaction mixture was stirred at $0{ }^{\circ} \mathrm{C}$ for $1 \mathrm{~h}$ and was warmed to rt. Stirring was continued overnight. Water was added and the organic layer was separated. The aqueous layer was extracted with EtOAc. The combined organic layers were washed with $1 \mathrm{M} \mathrm{HCl}, \mathrm{H}_{2} \mathrm{O}$, saturated $\mathrm{NaHCO}_{3}$ and brine, successively. The organic phases were dried $\left(\mathrm{Na}_{2} \mathrm{SO}_{4}\right)$, and evaporated. The crude product was purified by flash column chromatography on silica gel (petroleum ether/EtOAc $=5 / 1$ then $1 / 1$ ) to give $N$-Boc-5-ALA-Tyr$\mathrm{OBu}^{t}$ ester (6) as white foam $(3.17 \mathrm{~g}, 86 \%)$.

${ }^{1} \mathrm{H} \mathrm{NMR}\left(\mathrm{CDCl}_{3}\right) \delta 7.09$ (br d, $\left.J=8.3 \mathrm{~Hz}, 2 \mathrm{H}\right), 6.91($ br d, $J=8.3 \mathrm{~Hz}, 2 \mathrm{H}), 5.30$ (br s, $\left.1 \mathrm{H}\right), 5.03$ (br d, $J=7.9 \mathrm{~Hz}, 1 \mathrm{H}), 4.36-4.31(\mathrm{~m}, 1 \mathrm{H}), 3.98$ (br d, $J=4.7 \mathrm{~Hz}, 2 \mathrm{H}), 2.95$ (br d, $J=5.8 \mathrm{~Hz}, 2 \mathrm{H}$ ), 2.79-2.74 (m, 4H), $1.36(\mathrm{~s}, 9 \mathrm{H}), 1.34(\mathrm{~s}, 9 \mathrm{H}), 1.31(\mathrm{~s}, 9 \mathrm{H})$.

${ }^{13} \mathrm{C}$ NMR $\left(\mathrm{CDCl}_{3}\right) \delta 204.4,171.1,170.8,155.7,155.1,149.5,134.2,130.5,121.3,82.1,79.8$, 79.7, 54.9, 50.3, 37.8, 34.3, 28.3, 27.9.

HRMS (ESI +$) \mathrm{m} / \mathrm{z}(\mathrm{M}+\mathrm{H})^{+}$calculated for $\mathrm{C}_{28} \mathrm{H}_{43} \mathrm{~N}_{2} \mathrm{O}_{9}$ 551.2969. Found: 551.2965.

5-ALA-Tyr ester hydrochloride ((S)-5-(4-(2-ammonio-2-carboxyethyl)phenoxy)-2,5dioxopentan-1-aminium chloride) (1). To a solution of $N$-Boc-5-ALA-Tyr-OBu ${ }^{t}$ ester (6) (1.55 $\mathrm{g}, 1.0 \mathrm{mmol})$ in $\mathrm{CH}_{2} \mathrm{Cl}_{2}(5 \mathrm{~mL})$ at $0{ }^{\circ} \mathrm{C}$ was added TFA $(5 \mathrm{~mL})$ and the reaction mixture was stirred at $\mathrm{rt}$ overnight, then poured into a solution of $\mathrm{HCl}$-diethyl ether. The precipitate was filtered and washed rapidly with diethyl ether to give 5-ALA-Tyr ester hydrochloride (1) as a hygroscopic white solid, mp $174^{\circ} \mathrm{C}$-dec.

${ }^{1} \mathrm{H}$ NMR (DMSO-d 6 ) $\delta 7.31$ (br d, $J=8.5 \mathrm{~Hz}, 2 \mathrm{H}$ ), 7.06 (br d, $J=8.5 \mathrm{~Hz}, 2 \mathrm{H}$ ), 4.07 (br t, $J=6.2$ $\mathrm{Hz}, 1 \mathrm{H}), 4.00$ (s, $2 \mathrm{H}), 3.16-3.06(\mathrm{~m}, 2 \mathrm{H}), 2.93(\mathrm{t}, J=6.5 \mathrm{~Hz}, 2 \mathrm{H}), 2.82(\mathrm{t}, J=6.5 \mathrm{~Hz}, 2 \mathrm{H})$.

${ }^{13} \mathrm{C}$ NMR (DMSO-d $\left.\mathrm{d}_{6}\right) \delta 202.6,171.0,170.3,149.5,132.8,130.6,121.6,53.3,46.5,35.0,34.4$, 27.4 .

HRMS (ESI +$) \mathrm{m} / \mathrm{z}(\mathrm{M}+\mathrm{H})^{+}$calculated for $\mathrm{C}_{14} \mathrm{H}_{19} \mathrm{~N}_{2} \mathrm{O}_{5}$ 295.1294. Found: 295.1294 . Anal. Calcd. for $\mathrm{C}_{14} \mathrm{H}_{20} \mathrm{Cl}_{2} \mathrm{~N}_{2} \mathrm{O}_{5}$ : C, 45.79; H, 5.49; N, 7.63. Found: C, 45.49; H, 5.73; N, 7.34.

\section{Preparation of solutions.}

Solutions were prepared by dissolving the selected product (ALA or ALA-Tyr) at a concentration of $10 \mathrm{mg} / \mathrm{ml}$ in PBS. The $\mathrm{pH}$ of the solution was adjusted with a solution of $\mathrm{NaOH}$ $1 \mathrm{~N}$ if necessary. Solutions were stored either at temperature $\mathrm{T}=21^{\circ} \mathrm{C}$ or at $\mathrm{T}=4^{\circ} \mathrm{C}$ according to the needs of the study. Just before measurement, $50 \mu \mathrm{l}$ were sampled from the solution and diluted 10x with water. A sample of $100 \mu \mathrm{l}$ of this last solution was injected into the column.

\section{Detection of degradation products.}

The degradation products of the ALA derivatives were monitored by reverse-phase liquid chromatography, coupled to a mass spectrometer (Autoprep system (Waters)), equipped with pumps (2525 binary gradient module), column fluidics organizer, sample manager (2767), PDA detector and ZQ4000 ESI-MS.

The ionization mode was electrospray, positive mode, cone voltage was set at 25 volts, the source temperature was $100^{\circ} \mathrm{C}$, the mass range was $\mathrm{m} / \mathrm{z} 150-1000$ in $2 \mathrm{sec}$. The mobile phase 
was a water/acetonitrile (ACN) gradient: $\mathrm{A}: \mathrm{H}_{2} \mathrm{O} 99.89 \%$ - HCOOH $0.1 \%$ - TFA $0.01 \%$; B: $\mathrm{CH}_{3} \mathrm{CN} 90 \%-, \mathrm{H}_{2} \mathrm{O} 9.89 \%-\mathrm{HCOOH} 0.1 \%$ - TFA $0.01 \%$, varying along a 30 min gradient $(t$ $=0 \mathrm{~min}: 98 \%$ water and $2 \% \mathrm{ACN} ; t=20 \mathrm{~min}: 40 \%$ water and $60 \% \mathrm{ACN} ; t=21 \mathrm{~min}: 100 \%$

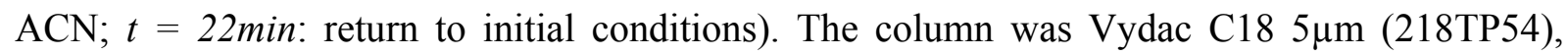
$4.6 \times 250 \mathrm{~mm}$ and flow rate was $1 \mathrm{~mL} / \mathrm{min}$.

Under those analytical conditions, more hydrophobic compounds are retained for longer times. ALA derivatives solutions were analyzed at various time points after their preparation $(0,30,60$, 120 minutes, $6 \mathrm{~h}$ and $24 \mathrm{~h}$ ). All measurements were performed twice and are expressed as the mean value of the two measurements with $67 \% \mathrm{CI}$.

\section{Acknowledgements}

The authors wish to thank the team of the laboratory SSMI (ISIC, EPFL), lead by Dr Laure Menin for their help with MS measurements and Dr Jérôme Barge for fruitful discussions. This work was supported by the Swiss National Science Foundation (Grant 205320-130518) and funded in part by the J. Jacobi Trust.

\section{References}

1. Babilas P.; Schreml S.; Landthaler M.; Szeimies R.M. Photodermatology, Photoimmunology \& Photomedicine 2010, 26, 118-132. http://dx.doi.org/10.1111/j.1600-0781.2010.00507.x PMid:20584250

2. Scarmato De Rosa, F.; Tedesco, A.C.; Fonseca Vianna Lopez, R.; Riemma Pierre, M.B.; Lange, N.; Maldonado Marchetti, J.; Gomes Rotta, J.C.; Lopes Badra Bentley, M.V. J Controlled Release, 2003, 89(2), 261-269. http://dx.doi.org/10.1016/S0168-3659(03)00125-1

3. Abels, C. Photochem. Photobiol. Sci. 2004, 3, 765-771 http://dx.doi.org/10.1039/b314241h PMid:15295633

4. Fotinos N.; Campo M.A.; Popowycz F.; Gurny R.; Lange N. Photochemistry and Photobiology 2006, 82, 994-1015. http://dx.doi.org/10.1562/2006-02-03-IR-794 PMid:16542112

5. Bech Gadmar, Ø.; Moan, J.; Scheie, E.; Ma, L-W.; Peng, Q. Journal of Photochemistry and Photobiology B: Biology. 2002, 67(3), 187-193. http://dx.doi.org/10.1016/S1011-1344(02)00278-6 
6. Novo M; Hüttmann G; Diddens H. Journal of Photochemistry and Photobiology B: Biology. 1996, 34, 143-148. http://dx.doi.org/10.1016/1011-1344(96)07285-5

7. Uehlinger, P.; Zellweger, M.; Wagnières, G.; Juillerat-Jeanneret, L.; van den Bergh, H.; Lange, N. Journal of Photochemistry and Photobiology B: Biology. 2000, 54(1), 72-80. http://dx.doi.org/10.1016/S1011-1344(99)00159-1

8. Bunke A.; Zerbe O.; Schmid H.; Burmeister G.; Merkle H.P.; Gander B. Journal of Pharmaceutical Sciences 2000, 89(10), 1335-1341. http://dx.doi.org/10.1002/1520-6017(200010)89:10<1335::AID-JPS11>3.0.CO;2-\#

9. Berkovitch, G.; Doron, D.; Nudelman, A.; Malik, Z.; Rephaeli, A. J. Med. Chem. 2008, 51, 7356-7369.

http://dx.doi.org/10.1021/jm8008794

PMid:19007111

10. Berger, Y.; Greppi, A.; Siri, O.; Neier, R; Juillerat-Jeanneret, L. J Med Chem 2000, 43, 47384746 .

http://dx.doi.org/10.1021/jm000981q

11. Donnelly R.F.; McCarron P.A.; Woolfson D. Perspectives in Medicinal Chemistry 2007, I, 49-63.

12. Kaliszewski M.; Kwasny M.; Juzeniene A.; Juzenas P.; Graczyk A.; Ma L.W.; Iani W.; Mikolajewska P.; Moan J. Journal of Photochemistry and Photobiology B: Biology. 2007, 87, 67-72.

http://dx.doi.org/10.1016/j.jphotobiol.2007.01.003 PMid:17350278

13. Pangborn, A. B.; Giardello, M. A.; Grubbs, R. H.; Rosen, R. K.; Timmers, F. J. Organometallics 1996, 15, 1518-1520. http://dx.doi.org/10.1021/om9503712

14. Schlienger, N.; Peyrottes, S.; Kassem, T.; Imbach, J.-L.; Gosselin, G.; Aubertin, A.-M.; Périgaud, C. J. Med. Chem. 2000, 43, 4570-4574.

http://dx.doi.org/10.1021/jm0009960 